\begin{tabular}{c|c|c}
\hline \hline Vol. 5: 303-309, 1981 & $\begin{array}{c}\text { MARINE ECOLOGY - ProGreSS SERIES } \\
\text { Mar. Ecol. Prog. Ser. }\end{array}$ & Published August 15 \\
\hline
\end{tabular}

\title{
Saturated Hydrocarbons in Marine Organisms
}

\author{
O. G. Mironov, T. L. Shchekaturina and I. M. Tsimbal \\ Institute of Biology of South Seas, Academy of Sciences USSR, 2, Nahimov St., Sevastopol, USSR
}

\begin{abstract}
Very few data are presently available on concentration levels of hydrocarbon in the marine biota. We have determined levels of saturated hydrocarbons in marine organisms. In fishes the hydrocarbon content totals $12-90 \mathrm{mg}(100 \mathrm{~g})^{-1}$ wet weight; in benthic and nekto-benthic animals, $7-200 \mathrm{mg}\left(100 \mathrm{~g}^{-1}\right.$. The hydrobionts examined contained a wide range of normal and branched alkanes, forming homologous series in some cases.
\end{abstract}

\section{INTRODUCTION}

The total hydrocarbon balance in the marine environment is the sum of autochthonous hydrocarbons, produced mainly by marine organisms, and allochthonous hydrocarbons, entering the sea as a result of man's activities. We do not take into account here natural seeps of hydrocarbons at the sea bottom because they are of little significance. Much has been written about hydrocarbons which enter the environment due to pollution and rather little is known about biogenic sources of hydrocarbons. The limited existing data indicate great ecological significance of the hydrocarbon compounds of hydrobionts (Blumer et al., 1964; Koons et al., 1965; Clark and Blumer, 1967; Love, 1970; Youngblood et al., 1971; Farrington and Meyers, 1973; Youngblood and Blumer, 1973).

Anthropogenic introduction of hydrocarbons into the marine environment may cause changes in biosynthesis of given compounds in the marine flora and fauna. If we consider only oil pollution, then these hydrocarbons make up ca $40 \%$ of the hydrocarbons produced in the seas by photosynthesis. On the other hand, during live or post-mortem release of hydrocarbons from marine organisms may increase the concentration of these compounds in the sea and they imitate oil pollution. Marine organisms are capable of accumulating oil hydrocarbons in their body. This fact provides (1) material for studying biogeochemical pathways in the transformation of these compounds, and (2) criteria for assessing oil pollution and measures for biomonitoring. Consequently, knowledge of natural hydrocarbon levels in marine organisms is a basic prerequisite for evaluating oil pollution
A critical review of the data available in the literature is difficult because of the variety of methods employed and the differences in concepts and aims. Thus, some authors give only a common number of hydrocarbons, others more detailed characteristics, in particular, of normal paraffins; still others differentiate between hydrocarbons of autochthonous and allochthonous origin (Lee et al., 1972; Brown et al., 1973; Stegeman and Teal, 1973; Clark and Finley, 1974; Anderson, 1975; Mironov and Shchekaturina, 1978; Tsimbal, 1979).

Regrettably, the majority of the data available on hydrocarbon contents in marine organisms were obtained at a time of expanding oil pollution. This makes it difficult to assess the background (natural) hydrocarbon concentration in marine biota.

In most cases the data at hand were obtained from samples taken in aquatoria with different oil-pollution levels, and often without quantitative and qualitative detail. According to Farrington and Meyers (1973) the hydrocarbon content varies from 1 to $200 \mu \mathrm{g} \mathrm{g}^{-1}$ to 545 $\mu \mathrm{g} \mathrm{g}^{-1}$ wet weight in polluted samples. (For summary of data see Bulletin of the US National Academy of Sciences, 1975.) However, if the data given for the open coastal and oceanic areas are taken to represent unpolluted conditions and the hydrocarbon content of hydrobionts to be of biogenic origin only, then we would have to differentiate between hydrocarbons of autochthonous and allochthonous origin. In an attempt to narrow the information gap, we have sampled and analysed large numbers of marine organisms sampled in different parts of the World Ocean scientific cruises conducted from 1975 to 1979. A comprehensive review on marine oil pollution will appear in Marine Ecology', Volume V. 


\section{MATERIAL AND METHODS}

Our material was taken from the Mediterranean Sea from 1975 to 1977; from the Atlantic Ocean in 1977; from the Indian Ocean in 1978 and from the Black Sea from 1975-1979. Collecting devices were trawls, fishing rods and landing nets. The organisms examined were dissected and fixed with a mixture of $\mathrm{CCl}_{4}$ and methanol $(2: 1)$.

Onshore sample treatment involved the following procedures: hydrocarbons were extracted by a double system of solvents $\mathrm{CCl}_{4}$-methanol $(2: 1)$ with successive lipid separation by column chromatography. The column was packed with silicagel ASK and $\mathrm{Al}_{2} \mathrm{O}_{3}$ (3:1). The ratio extract to adsorbent was $1: 50$. Both adsorbents were deactivated with water $15 \%$ of silicagel weight) so as to avoid artifacts. Hydrocarbons were eluted with hexane. Normal and branched alkanes were identified with a gas-chromatograph CHROM-3 with a flame-ionizating detector. A capillary column of $30 \mathrm{~m}$ length was packed with $5 \%$ Apieson. The temperature in the evaporation chamber was $300^{\circ} \mathrm{C}$. Analysis programming was at $2{ }^{\circ} \mathrm{C} \mathrm{min}-1$ up to $240^{\circ} \mathrm{C}$. The pressure in the column with gas carrier (helium) was $1 \mathrm{~atm}$. The sensitivity was $1: 1$. The fractions of methano-naphtenic hydrocarbons, and of aromatic and hetero-aromatic compounds were eluted from the hydrocarbon mixture on the microchromatograph column.

\section{RESULTS AND DISCUSSION}

The hydrocarbon contents of the marine hydrobionts examined are presented in Table 1. In fishes, the hydrocarbon content amounted to $12-90 \mathrm{mg}(100 \mathrm{~g})^{-1}$ wet weight, depending on the lipid content and/or on the degree of pollution of the habitat area. Thus, in the Mediterranean Sea, Sprattus sprattus, Mullus sp. and Sargus anularis contained the highest hydrocarbon amount: from 90 to $34 \mathrm{mg}(100 \mathrm{~g})^{-1}$ wet weight. These fishes also had a high lipid content. Fry of Mugil sp., taken in a polluted area, despite the relative low lipid content, contained more than $31 \mathrm{mg}(100 \mathrm{~g})^{-1}$ hydrocarbons (wet weight).

Fishes from the Indian Ocean revealed an identical picture. The total sum of hydrocarbons was highest in fishes sampled in the oil-impacted areas (Hemirhamphus Far, Tylosurus crocodilus) and in those containing high amounts of lipids (Alutera monoceros, Trachurus sp.).

The hydrocarbon content of fishes may also be associated with their physiological state (sexual maturity, sampling season, etc.). Perhaps this explains the differences in hydrocarbon contents of Odontogadus merlangus and Mugil saliens, taken in the Black Sea in winter. Winter is the time of fattening for $M$. saliens, but of intensive spawning for $O$. merlanugus; hence in the latter, the lipid supply is being exhausted during this period. In addition, the feeding habits of $M$. saliens, in particular grazing on overgrown rocks, tends to promote oil uptake. Mironov (1973) observed frequently that 1 -y-old Black Sea $M$. saliens gulped oil from the seawater surface; this oil was excreted and still filmed the aquarium surface even after fishes had been transferred to clean water.

Of the total hydrocarbons, 50-80\% make up the methanonaphthenic fraction; this, in turn, consists of $80 \%$ alkanes. Fishes from the Southern Seas contained: normal alkanes, 26-1248 $\mu \mathrm{g}(100 \mathrm{~g})^{-1}$ wet weight in the range of $\mathrm{C}_{1 !}-\mathrm{C}_{23}$ i branched alkanes, $4-966 \mu \mathrm{g}(100 \mathrm{~g})^{-1}$ wet weight in the range of $C_{14}-C_{20}$. These data are close to those given in the Bulletin of the US National Academy of Sciences (30-800 $\mu \mathrm{g}$ $100^{-1} \mathrm{~g} \mathrm{w}$. w.).

Almost all fishes examined featured hydrocarbons from $C_{12}$ to $C_{23}$, and several species, - e.g. Trachurus sp. caught in the Straits of Malacca - contained $C_{11}$. The latter is indicative of oil pollution. The same may be said about the fry of Mugil sp. and Sprattus sprattus sampled in the Mediterranean Sea. Their chromatograms revealed the presence of an unresolved background upon which n-alkane peaks of almost equal value were superimposed, and a homologous series of isoprenoides, i.e. indicators of oil pollution.

The remaining fishes contained alkanes in the range of $\mathrm{C}_{13}-\mathrm{C}_{19}$; hydrocarbons with odd carbon numbers $\left(C_{15}, C_{17}, C_{19}\right)$ dominated; $C_{15}$ predominated over $C_{16}$ and isoprenoides were absent. In exceptional cases, pristane occurred in several samples.

The content of saturated hydrocarbons in fishes may also be affected by the way of life and feeding. Possibly, in Gemphylus serpens the significant quantities of $\mathrm{C}_{15}$ and $\mathrm{C}_{21}$ may be due to the squid consumed; in the hydrocarbons contained in the squid, $\mathrm{C}_{15}$ predominated.

Among the branched alkanes, pristane dominated in almost all cases. In several cases its quantity exceeded that of individual normal alkanes; this may be due to the somewhat specific function of this hydrocarbon in fishes. In particular, Trachurus sp., sampled in three different areas of the Indian Ocean showed a pristane amount of $5.1-8.9 \mathrm{mg}(100 \mathrm{~g})^{-1}$ wet weight; other fishes, $0.6-3.9 \mathrm{mg}(100 \mathrm{~g})^{-1}$ wet weight. The high pristane content in Trachurus sp. is possibly typical for this species. According to Linko and Kaitaranta (1976), pristane is one of the major components in herring; in contrast anchovy have a low pristane content. The presence of other isoprenoides $\left(\mathrm{C}_{18}, \mathrm{C}_{20}\right)$ is not indica- 
Table 1 Hydrocarbon contents of marine organisms

\begin{tabular}{|c|c|c|c|c|c|c|}
\hline \multirow[t]{2}{*}{ Organisms } & \multirow{2}{*}{$\begin{array}{l}\text { Lipid } \\
\text { content } \\
\text { (g } 100 \mathrm{~g}^{-1} \\
\text { w.w.) }\end{array}$} & \multirow{2}{*}{$\begin{array}{l}\text { Hydro- } \\
\text { carbon } \\
\text { content } \\
\text { (mg } 100 \\
g^{-1} \text { w.w.) }\end{array}$} & \multicolumn{2}{|c|}{$\begin{array}{l}\text { Alkane range and content } \\
\qquad\left(\mathrm{mg} 100 \mathrm{~g}^{-1} \mathrm{w} . \mathrm{w} .\right)\end{array}$} & \multirow[t]{2}{*}{ Sum } & \multirow[t]{2}{*}{ Dominant } \\
\hline & & & Normal & Branched & & \\
\hline \multicolumn{7}{|c|}{ Indian Ocean (1978, VII, VIII) } \\
\hline Hemirhamphus far & 2.2 & 23.5 & $C_{12}-C_{20}(1174)$ & $C_{18}-C_{20}(730)$ & 1904.0 & $C_{17}$ \\
\hline Tylosurus crocodilus & 2.0 & 21.2 & $C_{12}-C_{20}(815)$ & $\mathrm{C}_{18}-\mathrm{C}_{20}(394)$ & 1209.0 & $\mathrm{C}_{i 5}^{17}$ \\
\hline Gempylus serpens & 2.2 & 14.1 & $C_{14}-C_{20}(405)$ & $C_{18}-C_{20}(187.2)$ & 592.2 & $\mathrm{C}_{15}$ \\
\hline Lethrinus sp. & 1.6 & 13.1 & $C_{13}-C_{20}(360.7)$ & $C_{18}-C_{20}(165)$ & 525.7 & $\mathrm{C}_{17}$ \\
\hline Sphyraena barracuda & 1.5 & 14.5 & $\mathrm{C}_{12}-\mathrm{C}_{20}(469)$ & $C_{18}-C_{20}(109)$ & 578.0 & $C_{15}$ \\
\hline Trachurus sp. & 2.2 & 16.7 & $C_{12}-C_{20}(794)$ & $C_{18}-C_{20}(966)$ & 1760.0 & $\mathrm{C}_{15}$ \\
\hline Trachurus sp. & 1.9 & 23.6 & $C_{12}-C_{20}(652)$ & $C_{18}^{10}-C_{20}(790)$ & 1442.0 & $\mathrm{C}_{15}$ \\
\hline Trachurussp. & 2.8 & 12.7 & $\mathrm{C}_{11}-\mathrm{C}_{20}(1248)$ & $\mathrm{C}_{14}-\mathrm{C}_{20}(789)$ & 2037.0 & $C_{15}$ \\
\hline Synodus sp. & 1.6 & 19.5 & $C_{12}-C_{20}(1136)$ & $\mathrm{C}_{18}-\mathrm{C}_{20}(272)$ & 1408.0 & $\mathrm{C}_{15}$ \\
\hline Mullus sp. & 2.5 & 16.6 & $C_{12}-C_{20}(428)$ & $C_{18}-C_{20}(150)$ & 578 & $C_{15}$ \\
\hline Alutera monoceros & 3.9 & 29.8 & $C_{12}-C_{20}(850)$ & $C_{16}, C_{18}-C_{20}(294)$ & 1144 & $\mathrm{C}_{17}$ \\
\hline Argyrops sp. & 2.7 & 16.2 & $C_{12}-C_{20}(602)$ & $C_{16}, C_{18}-C_{20}(575)$ & 1177 & $\mathrm{C}_{16}$ \\
\hline Tridacna squamosa & 1.2 & 9.5 & $\mathrm{C}_{12}-\mathrm{C}_{20}(423)$ & $C_{18}, C_{19}(46.7)$ & 469.7 & $C_{17}$ \\
\hline Tridacna squamosa & 1.5 & 9.9 & $C_{13}-C_{20}(125.4)$ & $C_{18}-C_{20}(44.4)$ & 169.8 & $C_{17}$ \\
\hline Lambis lambis & 0.5 & 9.1 & $C_{14}-C_{20}(171.7)$ & $C_{18}-C_{20}(66)$ & 237.7 & $\mathrm{C}_{17}$ \\
\hline Swimming crabs of Portunidae family & 1.9 & 13.1 & $C_{12}-C_{20}(181.5)$ & $C_{18}-C_{20}(92 . \overline{7})$ & 2742 & $\mathrm{C}_{17}$ \\
\hline Plankton, mainly Cypridina castanea & 1,3 & 20.0 & $C_{14}-C_{20}(735.6)$ & $C_{20}(19.6)$ & 755.2 & $C_{17}^{\prime \prime}$ \\
\hline Sthenotenthis oulaniaensis & 1.0 & 11.1 & $C_{12}-C_{20}(338)$ & $C_{18}-C_{20}(136)$ & 474.0 & $C_{15}$ \\
\hline \multicolumn{7}{|c|}{ Atlantic Ocean $(1977, X)$} \\
\hline Dentex sp. & 4.9 & 19.4 & $C_{15}-C_{20}(818.9)$ & not determined & 818.9 & $\mathrm{C}_{16}$ \\
\hline \multicolumn{7}{|c|}{ Mediterranean Sea $(1975, \mathrm{X}, \mathrm{XI})$} \\
\hline Sprattus sprattus & 2.1 & 90.2 & $C_{11}-C_{18}(967.4)$ & $C_{19}(391)$ & 1358.4 & $\mathrm{C}_{15}$ \\
\hline Mullus sp. & 1.6 & 64.2 & $C_{15}-C_{1819}(26)$ & $C_{19}(7.2)$ & 33.2 & $C_{19}$ \\
\hline Sparus sp. & 1.7 & 32.5 & $C_{15}-C_{17.18}(83.5)$ & $C_{19}(65.1)$ & 148.6 & $C_{15}$ \\
\hline \multicolumn{7}{|c|}{ Mediterranean Sea $(1975, \mathrm{X}, \mathrm{XI})$} \\
\hline Mugilsp. & 1.02 & 31.5 & $\mathrm{C}_{12}-\mathrm{C}_{19}(549)$ & $C_{14}-C_{19}(235.5)$ & 784.5 & $C_{17}$ \\
\hline Engraulis encrasicholus & 1.3 & 26.0 & $\mathrm{C}_{13}-\mathrm{C}_{18}(446.5)$ & $C_{19}-C_{20}(190.5)$ & 637 & $\mathrm{C}_{14}$ \\
\hline Belone belone & 1.02 & 15.2 & $\mathrm{C}_{13}-\mathrm{C}_{17}(462.5)$ & $\mathrm{C}_{17}, \mathrm{C}_{19}(17.2)$ & 479.7 & $\mathrm{C}_{15}$ \\
\hline Boops boops & 0.4 & 17.2 & $\mathrm{C}_{13}-\mathrm{C}_{19}(54.4)$ & $\mathrm{C}_{20}(4)$ & 58.4 & $\mathrm{C}_{15}$ \\
\hline Mytilus galloprovincialis & 0.7 & 9.9 & $\mathrm{C}_{13}-\mathrm{C}_{19}(1489.7)$ & $\mathrm{C}_{15}-\mathrm{C}_{20}(1386)$ & 2875.7 & $\mathrm{C}_{16}$ \\
\hline Acmaea virginea & 0.5 & 66 & $\mathrm{C}_{10}-\mathrm{C}_{18}(365.2)$ & $C_{15}, C_{19}(49)$ & 414.2 & $\mathrm{C}_{11}$ \\
\hline Chlamys opercularis & 0.3 & 69 & $\mathrm{C}_{14}-\mathrm{C}_{17}(423)$ & not determined & 423.0 & $\mathrm{C}_{17}$ \\
\hline Palaemon elegans & 0.4 & 8.7 & $\mathrm{C}_{12}-\mathrm{C}_{19}(86.4)$ & $C_{18}(11.5)$ & 97.9 & $\mathrm{C}_{19}$ \\
\hline Carcinas maenas & 0.3 & 3.4 & $\mathrm{C}_{10}-\mathrm{C}_{17}(19.1)$ & $\mathrm{C}_{19}(1.2)$ & 20.3 & $\mathrm{C}_{17}$ \\
\hline Paracentrotus lividus & 0.6 & 14 & $\mathrm{C}_{14}-\mathrm{C}_{18}(27.9)$ & $C_{19}(2.9)$ & 30.8 & $C_{17}$ \\
\hline Ophiophrix fragilis & - & 11.5 & $\mathrm{C}_{12}-\mathrm{C}_{18}(38.4)$ & $C_{15}, C_{17}, C_{18}, C_{20}(23.6)$ & 62.0 & $\mathrm{C}_{18}$ \\
\hline Loligo vulgaris & 0.3 & 18.7 & $\mathrm{C}_{12}-\mathrm{C}_{18}(106.3)$ & $\mathrm{C}_{15}-\mathrm{C}_{18}(37.6)$ & 143.9 & $\mathrm{C}_{15}$ \\
\hline Cucumariasp. & 0.3 & 7.6 & $C_{13}-C_{20}(21.2)$ & $\mathrm{C}_{16}-\mathrm{C}_{19}(4.2)$ & 25.3 & $\mathrm{C}_{18}$ \\
\hline \multicolumn{7}{|c|}{ Aegean Sea $(1977, X)$} \\
\hline Ophiophrix fragilis & 0.7 & 37.4 & $C_{14}-C_{20}(423)$ & $\mathrm{C}_{18}, \mathrm{C}_{19}(46.7)$ & 469.7 & $\mathrm{C}_{19}$ \\
\hline Cidaris sp. & 2.7 & 64.2 & $\mathrm{C}_{14}, \mathrm{C}_{18}, \mathrm{C}_{19}(152)$ & not determined & 152.0 & $\mathrm{C}_{19}$ \\
\hline Henricia sanquinolenta & 1.2 & 86.1 & $\mathrm{C}_{13}-\mathrm{C}_{20}(1070.9)$ & $\mathrm{C}_{15}-\mathrm{C}_{19}(514.6)$ & 1585.5 & $\mathrm{C}_{14}$ \\
\hline Clathrina sp. & 1.3 & 16.1 & $C_{13}-C_{20}(234.6)$ & $C_{18}, C_{19}(44.6)$ & 279.2 & $\mathrm{C}_{14}$ \\
\hline \multicolumn{7}{|c|}{ Black Sea $(1977, \mathrm{XI})$} \\
\hline Merlangus merlangus euxinus & 1.5 & 9.4 & $\mathrm{C}_{15}-\mathrm{C}_{20}(43.4)$ & $\left.\mathrm{C}_{18}-\mathrm{C}_{20} 616.4\right)$ & 59.8 & $\mathrm{C}_{16}$ \\
\hline Diplodus annularis & 8.5 & 34.4 & $\mathrm{C}_{13}-\mathrm{C}_{20}(473)$ & $C_{18}-C_{20}(68)$ & 541.0 & $\mathrm{C}_{17}$ \\
\hline Mytilus galloprovincialis & 2.0 & 19.7 & $\mathrm{C}_{12}-\mathrm{C}_{19}(258)$ & $C_{14}-C_{20}(77.5)$ & 335.5 & $\mathrm{C}_{14}$ \\
\hline Mytilus galloprovincialis & 2.5 & 200 & $C_{12}-C_{20}(1520)$ & $C_{14}-C_{20}(1789)$ & 3309 & $\mathrm{C}_{17}$ \\
\hline
\end{tabular}


tive of hydrocarbons of biogenic origin; it suggests pollution of organisms due to oil and oil products.

Fry of Mediterranean mugil have a wider range of normal alkanes $\left(\mathrm{C}_{12}-\mathrm{C}_{20}\right)$ and branched alkanes $\left(C_{14}-C_{19}\right)$ and fishes from the Southern Seas showed a wide range of normal and branched alkanes, both of biological and oil origin, in quantities ranging from 30 to $2547 \mathrm{mg}(100 \mathrm{~g})^{-1}$ wet weight. Among the normal alkanes, $\mathrm{C}_{15}$ dominated in most cases, followed by $\mathrm{C}_{17}$ and in one or two organisms $C_{16}$ and $C_{19}$. Among the branched alkanes, pristane dominated, and in one case also phytane.
The total hydrocarbon amount varies from 6.9 to 200 $\mathrm{mg}(100 \mathrm{~g})^{-1}$ wet weight in benthos and nekto-benthos organisms. This is likely due to variations in physiological state and/or environmental factors. In the Mediterranean Sea, mussels have a high hydrocarbon content [ $99 \mathrm{mg}(100 \mathrm{~g})^{-1}$ ] as have sea limpets [66 $\mathrm{mg}$ $(100 \mathrm{~g})^{-1}$. These organisms were taken in oil-polluted areas. The remaining Mediterranean organisms examined show ranges from 3.4 to $18.7 \mathrm{mg}\left(100 \mathrm{~g}^{-1}\right.$; normal and branched alkanes total $10-2333 \mu \mathrm{g} 100^{-1} \mathrm{~g}$ wet weight. In most cases, the dominating n-alkanes were $C_{17}$ ( 7 organisms), $C_{19}$ ( 3 organisms), $C_{14}, C_{15}$ and

Table 2. Hydrocarbon distribution in organs and tissues of marine animals

\begin{tabular}{|c|c|c|c|c|c|c|}
\hline Animal and organ & $\begin{array}{c}\text { Lipid } \\
\text { content } \\
\text { (mg } 100 \mathrm{~g}^{-1} \\
\text { w.W.) }\end{array}$ & $\begin{array}{c}\text { Hydro- } \\
\text { carbon } \\
\text { content } \\
\text { (mg } 100 \mathrm{~g}^{-1} \\
\text { w.w.) }\end{array}$ & $\begin{array}{r}\text { Alkane ra } \\
\text { (mg } 1\end{array}$ & $\begin{array}{l}\left.g^{-1} w . w .\right)\end{array}$ & Sum & Dominant \\
\hline \multicolumn{7}{|c|}{ Mediterranean Sea (1975) } \\
\hline Squalus sacanthias & & & & & & \\
\hline liver & 3.7 & 15.4 & $\mathrm{C}_{15}-\mathrm{C}_{19}(118.3)$ & $C_{19}(19.3)$ & 137.6 & $\mathrm{C}_{17}$ \\
\hline gonads & 1.0 & 5.3 & $C_{14}-C_{19}(37.9)$ & $C_{19}(8.7)$ & 46.6 & $C_{18}$ \\
\hline \multicolumn{7}{|l|}{ Merluccius merluccius } \\
\hline head & 0.9 & - & $\mathrm{C}_{13}-\mathrm{C}_{17}(28.9)$ & $C_{19}(4.5)$ & 33.4 & $\mathrm{C}_{17}$ \\
\hline body & 0.4 & - & $\mathrm{C}_{14}-\mathrm{C}_{18}(22.4$ & $\mathrm{C}_{19}(14.4)$ & 36.8 & $C_{15}$ \\
\hline liver & 2.8 & - & $C_{14}-C_{17}(250.8)$ & $C_{19}(720)$ & 322.8 & $C_{15}$ \\
\hline \multicolumn{7}{|l|}{ Scomber scombrus } \\
\hline gut & 0.3 & 16.8 & $C_{15}-C_{17}(19.3)$ & not determined & 19.3 & $\mathrm{C}_{15}$ \\
\hline head & 2.9 & 24.6 & $C_{16}, C_{17}(39.1)$ & not determined & 32.1 & $\mathrm{C}_{17}$ \\
\hline body & 1.9 & 19.2 & $C_{15}-C_{18}(32.2)$ & not determined & 32.2 & $C_{17}$ \\
\hline liver & 1.02 & 64.8 & $C_{11}-C_{17}(172.7)$ & not determined & 172.7 & $\mathrm{C}_{15}$ \\
\hline \multicolumn{7}{|l|}{ Trachurus trachurus } \\
\hline gut & - & 31.2 & $C_{13}-C_{17}(95.6)$ & not determined & 95.6 & $C_{16}$ \\
\hline body & - & 23.7 & $C_{15}-C_{18}(37.7)$ & not determined & 37.7 & $C_{13}$ \\
\hline \multicolumn{7}{|c|}{ Black Sea (1977) } \\
\hline \multicolumn{7}{|l|}{ Eriphia verrucosa } \\
\hline flesh & 4.03 & 18.6 & $\mathrm{C}_{14}-\mathrm{C}_{20}(32.6)$ & $C_{17}-C_{19}(4.7)$ & 44.3 & $C_{17}$ \\
\hline liver & 18.9 & 27.8 & $C_{13}-C_{20}(154.7)$ & $C_{15}-C_{17}, C_{19}(19.4)$ & 174.1 & $C_{16}$ \\
\hline gonads & 9.7 & 55.3 & $C_{14}-C_{20}(114.7)$ & not determined & 114.7 & $C_{17}$ \\
\hline \multicolumn{7}{|l|}{ Mugil auratus } \\
\hline flesh & 9.2 & 68.0 & $\mathrm{C}_{15}-\mathrm{C}_{19}(269.4)$ & $C_{19}, C_{20}(136)$ & 405.4 & $C_{19}$ \\
\hline head & 23.4 & 52.0 & $\mathrm{C}_{15}-\mathrm{C}_{20}(704)$ & $C_{15}-C_{20}(132.0)$ & 836.0 & $C_{15}$ \\
\hline internal organs & 24.05 & 79.0 & $\mathrm{C}_{15}-\mathrm{C}_{20}(472.9)$ & $C_{18}=C_{20}(169.4)$ & 642.3 & $C_{17}$ \\
\hline \multicolumn{7}{|c|}{ Indian Ocean (VIII, 1978) } \\
\hline \multicolumn{7}{|l|}{ Carhaihinus obscurus } \\
\hline liver & 41.7 & 248 & $\mathrm{C}_{13}-\mathrm{C}_{20}(8519)$ & $C_{19}, C_{20}(3111)$ & 11630.0 & $C_{16}$ \\
\hline \multicolumn{7}{|c|}{ Atlantics (1977) } \\
\hline \multicolumn{7}{|l|}{ Ommastrephes bartrami } \\
\hline head & 0.9 & 9.9 & $\mathrm{C}_{15}-\mathrm{C}_{20}(36.2)$ & $C_{18}(6.1)$ & 42.3 & $C_{16}$ \\
\hline flesh & 0.9 & 9.6 & $C_{15}-C_{17}(10.4)$ & $\mathrm{C}_{18}(2.8)$ & 13.2 & $C_{16}$ \\
\hline \multicolumn{7}{|l|}{ Zeussp. } \\
\hline flesh & 2.1 & 28.4 & $C_{15}-C_{19}(448.4)$ & $C_{19}(30.7)$ & 856.4 & $C_{15}$ \\
\hline internal organs & 18.0 & 14.8 & $C_{14}-C_{20}(4276)$ & $\mathrm{C}_{19}(499)$ & 4775.0 & $\mathrm{C}_{15}$ \\
\hline
\end{tabular}


$\mathrm{C}_{18}$ (1-2 organisms). Most representatives of this group of organisms contain a significant amount of isoprenoides, up to homologous series. And all of them may dominate.

The amount of individual alkanes was 20-90\% lower in Black Sea mussels from clean waters than in those from polluted areas. The fact that these mussels are strong filtrators tends to promote the accumulation of considerable quantities of hydrocarbons, especially in oil-containing waters.

The alkane (normal and branched) content in mussels from clean and polluted areas was about 400 and $1800 \mu \mathrm{g}(100 \mathrm{~g})^{-1}$ wet weight, respectively. Fossato and Siviero (1974) found a complex mixture of hydrocarbons in Mediterranean Mytilus galloprovincialis. The mixture included hydrocarbons of crude oil from 0.8 to $8.7 \mathrm{mg}\left(100 \mathrm{~g}^{-1}\right.$ wet weight. In several cases the values reached up to $22 \mathrm{mg}(100 \mathrm{~g})^{-1}$ wet weight, depending on the distance from the pollution source. As was pointed out above, qualitative aspects of the hydrocarbon content may depend on feeding habits. Perhaps this explains the similarity in the hydrocarbon content of Tridacna squamosa from two different areas in the Indian Ocean.

Thus, in some cases, similar to the fishes examined, benthos organisms contained a complex mixture of hydrocarbons comprising homologous series and testifying to the presence of oil pollution.

\section{Saturated Hydrocarbons in Some Organs and Tissues of Animals}

After entering the body of marine animals, hydrocarbons are stored differently in organs and tissues (Table 2). In fishes, the main organs for hydrocarbon uptake are liver and gall-bladder. However, Scomber scombrus revealed significant quantities of total hydrocarbons in its head. This is likely linked with the fact that the head of $S$. scombrus contains the highest number of lipids compared to other organs. Nevertheless, major quantities of n-alkanes were noticed in the liver as well. This fact confirms once more that the liver is one of the main organs for hydrocarbon uptake.

The n-alkane content in the liver of Mediterranean animals exceeds several times the quantity in other organs. It totals $130-318 \mu \mathrm{g}\left(100 \mathrm{~g}^{-1}\right.$ wet weight, versus $19.3-47.7 \mu \mathrm{g}(100 \mathrm{~g})^{-1}$ in other hydrobionts. The flesh of Black Sea crabs contains fewer hydrocarbons than liver and internal organs. The same is true for Mugil sp.

It is interesting to note that liver and gut of the test animals often revealed the presence of light hydrocarbons, such as $\mathrm{C}_{10}$ and $\mathrm{C}_{11}$. This is typical of oilimpacted samples. Oil hydrocarbons are aggregated in organs with a barrier function.

\section{Hydrocarbons in Algae}

Marine algae also contain differently-structured hydrocarbons. We analysed the hydrocarbon content of 6 Mediterranean species and 11 Black Sea algae. Some characteristics of the hydrocarbon content of algae are presented in Table 3. Algae contain a non-complex mixture of unbranched alkanes. Red algae sampled in the Mediterranean and Black Sea exhibit a predominance of normal heptadecanes, the only normal paraffin in the 3 red algae tested: Callithamnion corymbosum, Phyllophora nervosa, Polysiphonia elongata.

Two Mediterranean macrophytes Polysiphonia furticulosa and Vidadia volubia, contained in addition to $C_{17}$, low quantities of $C_{16}$. Ceramium rubrum and Corallina officinalis revealed a wider range of $n$ alkanes, i.e. from $\mathrm{C}_{15}$ to $\mathrm{C}_{24}$. In Ulva sp. and two species of Enteromorpha, n-pentadecane was most typical. No branched alkanes were identified by us in algal thallomes except in $C$. officinalis.

Along with $n$-alkanes in the range of $\mathrm{C}_{13}-\mathrm{C}_{26}$ in macrophytes, Clark and Blumer (1967) revealed pristane in Ascophyllum crimbrosum and Laminaria digitata. However, pristane is not typical of most red algae which were the essential test material. As the authors stated, $n$-heptadecane was most typical for red algae.

In order to compare clean and polluted samples we made chromatogram spectra for normal paraffins of one and the same algal species, taken from different polluted areas. Thallomes from polluted areas were thoroughly washed with solvents until luminescence disappeared from their surface. While Callithamnion corymbosum from clean water contain only n-alkanes

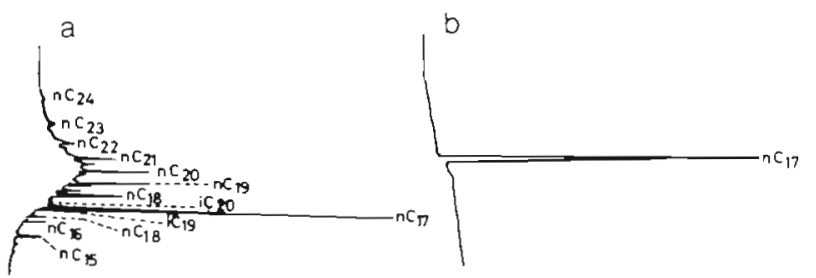

Fig. 1. Callithamnion corymbosum. Hydrocarbon content of alga from polluted water (a) and from clean water (b)

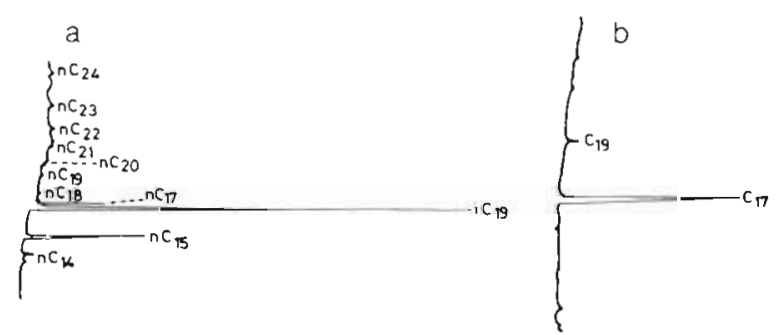

Fig. 2. Enteromorpha intestinalis. Hydrocarbon content of alga from polluted water (a) and from clean water (b) 


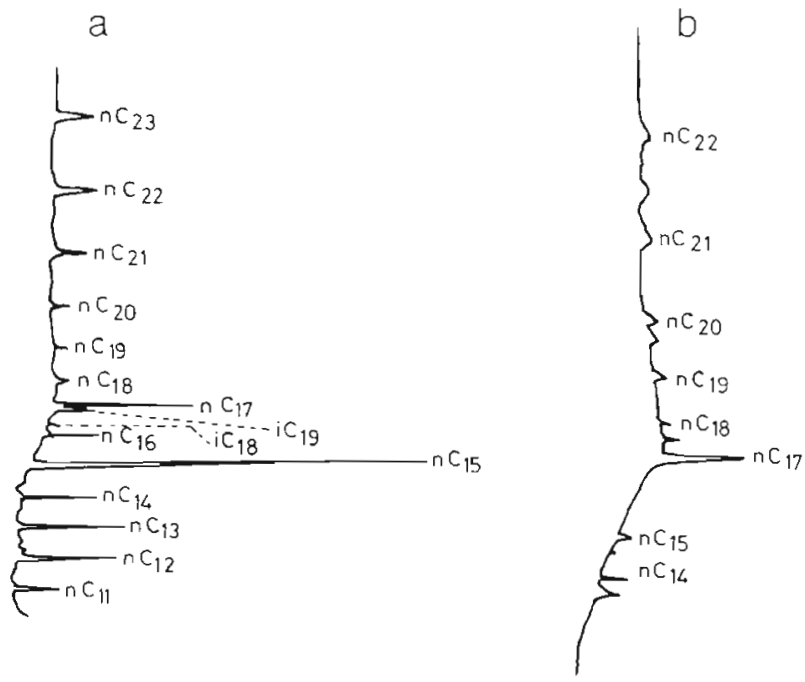

Fig. 3. Ulva rigida. Hydrocarbon content of alga from polluted water (a) and from clean water (b)

with $\mathrm{C}_{17}$ (Fig. 1a), conspecifics from polluted waters contained unbranched alkanes in the range of $\mathrm{C}_{15}-\mathrm{C}_{25}$, as well as phytane and pristane simultaneously in the hydrocarbon fraction (Fig. 1b). According to Rossi et al. (1978) the latter is an indicator of algal pollution by oil hydrocarbons.

The hydrocarbons in Enteromorpha intestinalis are represented by $n$-alkanes $\mathrm{C}_{17}$ and $\mathrm{C}_{19}$ (Fig. 2a). Polluted $E$. intestinalis contained paraffins from $C_{14}$ to $C_{24}$. Pristane exceeded several times the sum of all paraffins (Fig. 2b).
Unbranched alkanes were identified in Ulva rigida from $\mathrm{C}_{14}$ to $\mathrm{C}_{22}$ (Fig. 3a) with $\mathrm{n}-\mathrm{C}_{17}$ predominance. $U$. thallomes from polluted areas contained low-boiling hydrocarbons $\mathrm{C}_{11}$ to $\mathrm{C}_{13}$ as well as the isoprenoides $\mathrm{i}$ $\mathrm{C}_{18}$, i- $\mathrm{C}_{19}$ (Fig. 3b). Thus, samples from the same algal species taken from different areas showed significant divergences on the chromatograms.

Assessments of the general significance of hydrocarbons in the ecology and taxonomy of organisms require careful consideration and extreme precaution not least because of the presence of hydrocarbons typical of oil pollution.

\section{LITERATURE CITED}

Anderson, J. W. (1975). Laboratory studies on the effects of oil on marine organisms. Q. Am. Petrol. Inst. 4249: 1-70

Blumer, M., Mullin, M. M., Thomas, P. W. (1964). Pristane in marine environment. Helgoländer wiss. Meeresunters. 10: $187-201$

Brown, R. A., Searl, T. D., Elliot, J. J., Phillips, B. Q., Brandon, D. E., Monaghan, P. H. (1973). Distribution of heavy hydrocarbons in some Atlantic Ocean water. In: Proc. Joint Conf. on Prevention and Control of Oil Spills. Am. Petrol. Inst., Washington, pp. 509-519

Clark, R. C., Blumer, M. (1967). Distribution of n-paraffins in marine organisms and sediments. Limnol. Oceanogr. 12: $79-87$

Clark, R. C., Finley, J. S. (1974). Techniques for analysis of paraffin hydrocarbons and tar interpretation data to assess oil spill effects in aquatic organisms. In: Proc. Joint Conf. on Prevention and Control of Oil Spills. Am. Petrol. Inst., Washington, pp. 161-172

Table 3. Hydrocarbon contents of Black Sea algae

\begin{tabular}{|c|c|c|c|c|}
\hline \multirow{2}{*}{ Algae } & \multirow{2}{*}{$\begin{array}{l}\text { Hydrocarbon } \\
\text { content } \\
\mathrm{mg} 100 \mathrm{~g}^{-1} \mathrm{w} . \mathrm{w} .\end{array}$} & \multicolumn{2}{|c|}{ Alkanes ( $\mu \mathrm{g} 100 \mathrm{~g}^{-1}$ w.w.) } & \multirow{2}{*}{ Dominant } \\
\hline & & normal & branched & \\
\hline Callithamnion corymbosum & 7.4 & $\mathrm{C}_{17}(23.1)$ & not determined & $\mathrm{C}_{17}$ \\
\hline Callichamnion corymbosum & 39.9 & $\mathrm{C}_{15}-\mathrm{C}_{25}(420.9)$ & 43.9 & $\mathrm{C}_{17}$ \\
\hline Polysiphonia elongata & 7.6 & $\mathrm{C}_{17}(20.2)$ & not determined & $C_{17}$ \\
\hline Phyllophora nervosa & 5.5 & $C_{17}(6.5)$ & not determined & $\mathrm{C}_{17}$ \\
\hline Corallina officinalis & 6.3 & $\mathrm{C}_{14}-\mathrm{C}_{23}(8.5)$ & 0.2 & $C_{17}$ \\
\hline Corallina officinalis & 12.7 & $C_{15}-C_{24}(21.2)$ & 2.9 & $C_{17}$ \\
\hline Ceramium rubrum & 11.4 & $C_{15}-C_{24}(82.4)$ & 6.8 & $C_{17}$ \\
\hline Grateloupia dichoroma & 10.8 & $\mathrm{C}_{15}-\mathrm{C}_{21}(282.1)$ & 103.7 & $\mathrm{C}_{17}$ \\
\hline Ulva rigida & 8.3 & $C_{14}-C_{24}(12.2)$ & not determined & $C_{15}$ \\
\hline Ulva rigida & 13.8 & $C_{13}-C_{21}(21.4)$ & not determined & $C_{15}$ \\
\hline Enteromorpha intestinalis & 9.2 & $\mathrm{C}_{15}-\mathrm{C}_{18}(13.8)$ & not determined & $C_{15}$ \\
\hline Enteromorpha intestinalis & 19.3 & $C_{13}-C_{21}(93.1)$ & not determined & $C_{15}$ \\
\hline Enteromorpha clathrata & 5.0 & $C_{15}(22.0)$ & not determined & $C_{15}$ \\
\hline Cladostephus verticilacus & 1.2 & $C_{11}-C_{23}$ (traces) & not determined & $\mathrm{C}_{17}$ \\
\hline Cystoseira barbata & 10.5 & $\mathrm{C}_{14}-\mathrm{C}_{20}$ (traces) & not determined & $\mathrm{C}_{17}$ \\
\hline Punktaria latifolia & 7.7 & $C_{14}-C_{20}(276)$ & not determined & $C_{14}$ \\
\hline Sargassum vulgaris & 5.8 & $\mathrm{C}_{14}-\mathrm{C}_{19}(234)$ & not determined & $\mathrm{C}_{1+}$ \\
\hline Polysiphonia furriculosa & 13.7 & $C_{16}, C_{17}(633)$ & not determined & $\mathrm{C}_{17}$ \\
\hline Vidadia volubia & 4.7 & $C_{16}^{16}, C_{17}(326)$ & not determined & $C_{17}$ \\
\hline Phyllophora nervosa & 14.6 & $C_{16}, C_{18}(229)$ & not determined & $\mathrm{C}_{17}$ \\
\hline Codium bursa & 11.6 & $C_{16}, C_{17}(157)$ & not determined & $C_{17}$ \\
\hline
\end{tabular}


Farrington, J. W., Meyers, P. A. (1973). Hydrocarbons in marine environment, U. K., Chem. Soc., London

Fossato, V U., Siviero, E. (1974). Oil pollution monitoring in the Lagoon of Venice using the mussel Mytilus galloprovincialis. Mar Biol. 25: 1-6

Koons, C. B. Jamieson, G. W., Cicroszko, L. S. (1965). Normal alkane distribution of marine origin. Bull. Am. Ass. Petrol. Geol. 49: 301-304

Lee, R. F., Saurheber, R., Benson, A. A. (1972). Petroleum hydrocarbons uptake and discharge by the marine Mytilus edulis. Science, N.Y. 177: 344-346

Linko, R. R., Kaitaranta, J. (1976). Hydrocarbons of Baltic herring lipids. Riv. ital. sostanze grasse, 3 (3), 37-39

Love, R. M. (1970). The chemical biology of fishes, Academic Press, London

Mironov, O. G. (1973). Oil pollution and the life of the sea. Naukova dumka, Kiev 1973: 35-39

Mironov, O. G., Shchekaturina, T. L. (1978). On the hydrocar- bon content of blacksea mussels. Zool. Zh. 8 (15): $1250-1252$

Rossi, S., Rommel, G. W., Benson, A. A. (1978). Hydrocarbons of Macrocystis pyrifera blades. Photochemistry 17: $1431-1433$

Stegeman, J. J., Teal, J. M. (1973). Accumulation, release and retention of petroleum hydrocarbons by the oyster Crassostrea virginica. Mar. Biol. 22:37-44

Tsimbal, I. M. (1979). Normal and branched alkanes in algae of the Black Sea. In: Proc. 3d All-Union Conference on Marine Algae and Macrophytobenthos, Sevastopol, pp. 128-129

Youngblood, W W., Blumer, M., Guilard, R. L., Fiore, R (1971). Saturated and unsaturated hydrocarbons in marine benthic algae. Mar. Biol. 8 (3): 130-201

Youngblood, W W., Blumer, M. (1973). Alkanes and alkenes in marine benthic algae. Mar. Biol. 21 (3): 163-172

This paper was presented by Professor A. V. Zhirmunsky; it was accepted for printing on April 7, 1981 